\title{
The Role Corn Varieties on Biomass, Stomata and Cholorophyll on a Nutrient Stress
}

\author{
Bukhari $^{1}$, Nuryulsen Safridar ${ }^{2}$ \\ ${ }^{1,2}$ University of Jabal Ghafur, Aceh Indonesia \\ bukharimp@gmail.com
}

\begin{abstract}
This study conducted on Soil and Plant of Laboratory, Screen House Experimental Farms on 2016 July until December on Agricultural Faculty, Syiah Kuala University, Darussalam Banda Aceh, Indonesia. This study used a Randomized Completely Design (RCD) with 36 treatments and three replications. They are have two factors such as Varieties have 9 procedures, and nutrient stress have 4 treatments. The parameter was observed on biomass, a total of stomata and chlorophyll. The result showed that varieties and nutrient stress were significantly on biomass, the whole of stomata and chlorophyll. The best of biomass was found on Sri Kandi kuning, and the lowest was found on anoman 1. The best of a total of stomata was found on anoman 1 and the lowest was found on sukmaraja. The heavy of chlorophyll was found on bima and the lowest was found on anoman 1. The best biomass was found on the nutrient of stress in formula $A B$ and the lowest was found on magnesium. The best stomata on nutrient stress were found on formula $A B$, and the lowest was found on magnesium. The heavy of chlorophyll on stress hara was found formula $A B$ and the lowest was found on Kalium. The best combination on biomass was found Sri Kandi Kuning and formula AB, the lowest was found on anoman 1 dan magnesium. The best combination on stomata was found on gumarang and formula $A B$, dan the lowest was found on sukmaraja dan magnesium.
\end{abstract}

Keywords: corn; varieties; nutrient stress; biomass; stomata; chlorophyll

\section{Introduction}

Corn is necessary to increase of growth economic of Aceh. The market of largest and land are potential to consider, but the availability of soil is dry land such as Ultisol (BPS, 2015). Ultisol has characteristics of deficit of water and deficient nutrients. According to of Jaleel et al., 2009; Zang, 2007; Wang dan Sangguan, 2010; Aminian et al., 2011: deficiency of water and deficient nutrients can decrease that growth of root, leaf, a total of stomata, chlorophyll and biomass.

The research of Feng et al., (2013) deficiency of Phosphor, Kalium and Magnesium can be decreased on the tissue of plant which not perfect. The research of Devid et al., (2010) on corn which planted on dry land was revealed best respect if that plant availability of water. This problem can be controlled by using the best varieties - the purpose of the study to get the best types of corn on the tissue of a plant under nutrients stress.

\subsection{Study of place}

\section{Materials and Method}

This research was investigated on Teureubeuh Village of Jantho Aceh Besar District of Indonesia. The temperature had 22-35 oC, elevation 100 sea levels. 05o17'05.2-95o35'12,1. The experiment of adaption on drought stress, $\mathrm{K}$ and $\mathrm{Mg}$ were observed at the laboratory of soil and plant, Screen House Experimental Farms Agricultural of Faculty, Syiah Kuala University Darussalam, Aceh, Indonesia from 2016 July until December.

\subsection{Ultisol}

As media planting used Ultisol on Teureubeuh Village of Jantho Aceh Besar District of 
Indonesia. The analyze was reveals this soil has tecsturs tanah clay sandy loam, massa is $0,97-$ $1,24 \mathrm{~g} \mathrm{~m}^{-3}$. Water $\mathrm{pF} 2,5$ is $22,6-39,2 \%$. $\mathrm{pF} 4,2$ is $12,5-15,8 \%$. Water of ability is $9,6-23,4 \%$. Permeability is $24,0-4,14 \mathrm{~cm} /$ day. Porosity is $36,5-41,8 \%$. Indec agregat is $34,1-36,7 . \mathrm{pH}_{2} \mathrm{O}$ is $6,02-6.60$. $\mathrm{C}$ organic only $0,32-1.79$ while $\mathrm{N}$ totally is $0,11-0,20 \%$. for $\mathrm{P}$ total only $6-10$ $\mathrm{Mgkg}^{-1}$., K-total is 3-4 mg $100 \mathrm{~g}^{-1}$ while $\mathrm{P}$ ability is $0,9-2,8 \mathrm{ppm}$. Ca is $1,54-4,75 \mathrm{Cmol} \mathrm{kg}^{-1}$. $\mathrm{Mg}$ is $0,67-0,81 \mathrm{Cmol} \mathrm{kg}_{-1}$. $\mathrm{K}$ is $0,10-0,20 \mathrm{Cmol} \mathrm{kg}^{-1}$. $\mathrm{Na}$ is $0,75-0,85 \mathrm{Cmol} \mathrm{kg}^{-1}$. capasity exchange cation are $3,13-6,59 \mathrm{Cmol} \mathrm{kg}^{-1}$. CEC is $20-26$. acidity potensial on $\mathrm{Al}$ negative while $\mathrm{H}$ is negativ $\mathrm{Cmol} \mathrm{kg-1}$. EC $0,04 \mathrm{mscm}^{-1}$ Basa is $12-33 \%$.

\subsection{Corn}

Varieties was used Anoman 1, Lamuru, Mortar, Gumarang, Srikandi Kuning, Sukmaraja, Bisma, Kresna, NK 212, NK jumbodan, Hibrida Bisi 12.

\subsection{Nutrient Stress}

Formula was used are mix formulasi A dan B. Kalium was gave on 1,8 g at 35 days (15 liter $\mathrm{AB}$ mix).

\subsection{Analyze data}

The research was used rendomize completely design. Analyze data was used microsoft excel.

\subsection{Para meter was observed}

a. Density and Index stomata

Density and Index stomata were observed on 30 days and took that leaf which has opened the perfect, this used jangkar so that have a diameter $0,5 \mathrm{~cm}$ from 3 shoots, then fixation on alcohol $70 \%$, and then it's cleaned by equates, soaked on the formulation of HNO3 $25 \%$ on 20 times for damaged that tissue of mesofil than clean again by equates, than that undercut on a knife and soaked with bicycling on three times. And then that leaf put on preparation with glycerin $10 \%$ and under microscope. Density and Index stomata were analyzed on rumus Lestari (2006) :

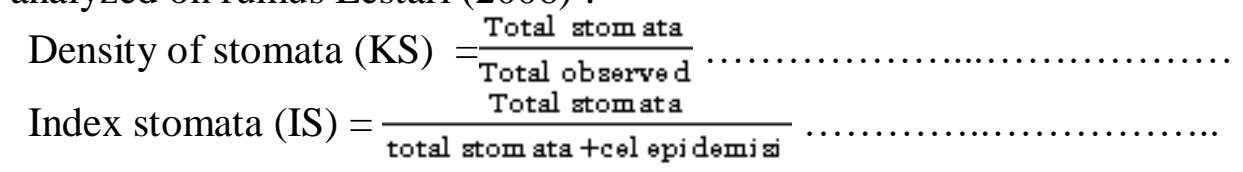

b. Chlorophyll

Chlorophyll was analyzed on Food of Laboratory, and Chlorophyll was recovery after deficiency of water. This leaf took and weighed with scale $0,05 \mathrm{~g}$, then added $2 \mathrm{~mm}$ acetone 80 $\%$, then it is mashed up with a mortar and than homogenate was taking on $2 \mathrm{ml}$ and entering on microfilter than centrifuge on $5.410 \mathrm{rpm}$ on 20 detic for separate supernatant from a plant. Ekstraxsi did more until has none colour. Supernatant Diptera $10 \mathrm{ml}$ and was investigated with spectrophotometer on the length of gelombang $645 \mathrm{~nm}$ for chlorophyll A and B the range of gelombang $663 \mathrm{~nm}$, chlorophyll A dan B by using this formulas :

Chlorophyll A $(\mathrm{mg} / \mathrm{mg}$ sample $)=\frac{(12,7 \times \mathrm{A} 663)-(2,69 \times \mathrm{A} 645))}{\text { heavy sampel }(\mathrm{mg})} \times \mathrm{Fp} \ldots \ldots \ldots .$.
Chlorophyll B $(\mathrm{mg} / \mathrm{mg}$ sample $)=\frac{((129 \times \mathrm{A} 645)-(4,68 \times \mathrm{A} 645))}{\text { heavy sampel (mg) }} \times \mathrm{Fp} \quad \ldots . \ldots \ldots$

$\mathrm{Fp}($ factor formulation $)=\frac{10 \mathrm{ml} \times 1 \mathrm{biter}}{1000 \times \mathrm{w}}$

Chlorophyll total $(\mathrm{g} / \mathrm{g}$ tissue $)=20,2 \times$ A $645 \times 8,02 \times \frac{v}{1000 \times \mathrm{wl}}$

C. Biomass was produce on biometric from roots under drought conditions $\mathrm{x}$ biomass

on control. 
Produce on average (MR) :

$\mathrm{MR}=\left(\mathrm{Y}_{\mathrm{s}}+\mathrm{Y}_{\mathrm{p}}\right) / 2$

\section{Results and Discussion}

\subsection{Varieties}

Table 1 illustrated varieties was significantly on biomass, total of stomata and chlorophil. The best biomass was found on srikandi kuning and the lowest was found on anoman 1 . The total of stomata was found on anoman 1 and the lowest was found on sukmaraja. chlorophil was found on bima and the lowest was found on anoman 1.

Table 1. Varieties on biomass on nutrient stress

\begin{tabular}{|c|c|c|c|c|c|}
\hline treatment & $\mathrm{L}$ & $-\mathrm{P}$ & $-\mathrm{K}$ & $-\mathrm{Mg}$ & $\begin{array}{c}\text { avarage } \\
(\mathrm{P})\end{array}$ \\
\hline $\mathrm{V} 1$ & 2.86 & 1.43 & 1.19 & 2.93 & 1.83 \\
\hline $\mathrm{V} 2$ & 5.97 & 3.17 & 3.76 & 3.50 & 4.30 \\
\hline $\mathrm{V} 3$ & 4.50 & 3.22 & 1.75 & 3.14 & 3.16 \\
\hline $\mathrm{V} 4$ & 11.49 & 2.52 & 4.18 & 2.87 & 6.06 \\
\hline $\mathrm{V} 5$ & 7.90 & 3.00 & 4.58 & 4.01 & 5.16 \\
\hline $\mathrm{V} 6$ & 5.81 & 3.36 & 4.84 & 2.13 & 4.67 \\
\hline $\mathrm{V} 7$ & 5.38 & 5.01 & 3.58 & 2.84 & 4.66 \\
\hline $\mathrm{V} 8$ & 2.48 & 2.11 & 2.59 & 1.39 & 2.39 \\
\hline V9 & 4.60 & 4.60 & 2.97 & 2.10 & 4.06 \\
\hline Average (U) & 5.67 & 3.16 & 3.27 & 2.77 & \\
\hline
\end{tabular}

On this result the observed on srikandi kuning was produce heavy biomasa than anoman 1. It's caused of srikandi kuning has a different of genetic than others. The research of Bukvice et al., (2011) said the plan can be respect every varieties which has heavy of biomass it's.

While on total of stomata was found on anoman 1 are more heavy than sukmaraja, it's caused stomata on top leaf anoman 1 more opened than sukmaraja, besides that, it's caused 2 factor are availability of water and intensitas of sun which was received from leaf on anoman 1, so that on anoman 1 more availability suplay of sun than sukmaraja. Stomata can be opened or closed on every condition.

The research of Jezek et al., (2015); Janmohammadi et al., (2008) dan Kavari (2009) said the more of the total stomata whiches found on a leaf because that leaf is the more received sun which was that stomata could spread on sheet from best varieties.

As well as with chlorophyll, the more fertile will produce the better the plant, but chlorophyll only able on a plant which can be photosynthesis better. The research of Naghav et al., (2013) said chlorophyll was decreased by water stress, so photosynthesis was damaged. If photosynthesis damage, it can produce the lowest. According to Rabbani et al., (2011), photosynthesis are process physiology which has important on a plant which catches the sun and change chemistry than saved on carbohydrate.

\subsection{Nutrient Stress}

Table 2 describes the nutrient stress was significantly on biomass, total stomata and chlorophyll. The best biomass was found on formulation $\mathrm{AB}$, and the lowest was found on magnesium. The best stomata were found on formulation $A B$, and most moderate was found on magnesium. The best chlorophyll was found on formulation $\mathrm{AB}$ dan lowest was found on Kalium. 
Budapest International Research in Exact Sciences (BirEx) Journal Volume 2, No 2, April 2020, Page: 141-146 e-ISSN: 2655-7827 (Online), p-ISSN: 2655-7835(Print) www.bircu-journal.com/index.php/birex emails: birex.journal@gmail.com

Table 2. Varieties on stomata on nutrient stress

\begin{tabular}{|c|c|c|c|c|c|}
\hline treatment & $\mathrm{L}$ & $-\mathrm{P}$ & $-\mathrm{K}$ & $-\mathrm{Mg}$ & $\begin{array}{c}\text { Average } \\
(\mathrm{P})\end{array}$ \\
\hline $\mathrm{V} 1$ & 219.00 & 222.67 & 93.33 & 101.00 & 178.33 \\
\hline V2 & 81.00 & 100.00 & 119.00 & 57.00 & 100.00 \\
\hline V3 & 253.67 & 136.33 & 135.00 & 116.67 & 175.00 \\
\hline V4 & 205.67 & 115.00 & 113.00 & 75.00 & 144.56 \\
\hline V5 & 71.67 & 95.00 & 125.00 & 70.67 & 97.22 \\
\hline V6 & 104.33 & 107.67 & 115.00 & 103.00 & 109.00 \\
\hline V7 & 250.67 & 127.00 & 100.33 & 95.00 & 159.33 \\
\hline V8 & 140.33 & 151.33 & 68.33 & 81.00 & 120.00 \\
\hline V9 & 190.67 & 72.67 & 64.00 & 105.00 & 109.11 \\
\hline Average(U) & 168.56 & 125.30 & 103.67 & 89.37 & \\
\hline
\end{tabular}

Magnesium (Mg) is a nutrient of mineral, which has essentially needed by using plant (Jezek et al., 2015). The role of magnesium will be necessary on photosynthesis such as atom central from others (Katerji et al., 2012; Cakmak et al., 2008). Deficiency Mg produces from more availability of cation, which has licking on soil sandy loam with the lowest capacity exchange cation (Ahmad et al., 2015; Gransee et al., 2013). It's all consequence of not balanced nutrient on soil and magnesium on fields. According to Cakmak dan Kirkby (2008). not stable of magnesium on fields can be decreased and deficiency of the nutrient.

The study of Cakmak and yazici (2010); Hardter et al., (2004), As well as deficiency of calcium, can produce the lowest of decreased of biomass, a total of stomata and chlorophyll. This research reveals the levels of nutrients was influencing on the ph of the soil.

\subsection{Interaction}

Table 3 showed substantial interaction on biomass, a total of stomata and chlorophyll. The best biomass was found on the combination between gumarang and formulation of $\mathrm{AB}$ dan the lowest was found on combination anoman 1 and kalium. The total of stomata was found on combination mortar, and formulation $\mathrm{AB}$ and the lowest was found on combination bisi 12 and kalium. The best chlorophyll was found on combination NK jumbodan dan $\mathrm{P}$, and the lowest was found on combination lamuru dan $-\mathrm{K}$.

Table 3. Varieties on cholorophil on nutrient stress

\begin{tabular}{|c|c|c|c|c|c|}
\hline treatment & $\mathrm{L}$ & $-\mathrm{P}$ & $-\mathrm{K}$ & $-\mathrm{Mg}$ & $\begin{array}{c}\text { Average } \\
(\mathrm{P})\end{array}$ \\
\hline $\mathrm{V} 1$ & 534.16 & 816.52 & 227.64 & 787.14 & 526.11 \\
\hline $\mathrm{V} 2$ & 1034.71 & 322.00 & 1107.95 & 825.09 & 821.55 \\
\hline $\mathrm{V} 3$ & 843.77 & 1185.74 & 1277.95 & 936.95 & 1102.48 \\
\hline $\mathrm{V} 4$ & 1240.15 & 885.87 & 825.73 & 1316.34 & 983.92 \\
\hline $\mathrm{V} 5$ & 1202.83 & 944.96 & 1256.50 & 921.14 & 1134.76 \\
\hline $\mathrm{V} 6$ & 1216.33 & 1166.25 & 1209.37 & 896.48 & 1197.32 \\
\hline $\mathrm{V} 7$ & 1237.66 & 713.87 & 811.47 & 997.51 & 921.00 \\
\hline $\mathrm{V} 8$ & 991.95 & 1199.34 & 1242.22 & 754.98 & 1144.50 \\
\hline V9 & 995.50 & 1445.29 & 304.52 & 1006.80 & 915.10 \\
\hline Avarage (U) & 1033.01 & 964.43 & 918.15 & 938.05 & \\
\hline
\end{tabular}


From result before the research, finding yet about best varieties of corn to control on condition of nutrient stress. This research is the first did of an experiment about nutrient stress on corn, which has done as a test to get the best varieties with adapted on drought condition.

\section{Conclusion}

The result showed that varieties and nutrient stress were significantly on biomass, a total of stomata and chlorophyll. The best of biomass was found on Sri Kandi Kuning, and the lowest was found on anoman 1 . The best of total of stomata was found on anoman 1 and the lowest was found on sukmaraja. The heavy of chlorophil was found on bima and the lowest was found on anoman 1 . The best biomasa was found on nutrient of stress in formula $\mathrm{AB}$ and the lowest was found on magnesium. The best stomata on nutrient stress were found on formula $\mathrm{AB}$, and the lowest was found on magnesium. The heavy of chlorophyll on stress hara was found formula $\mathrm{AB}$ and the lowest was found on Kalium. The best combination on biomass was found Sri Kandi Kuning and formula $A B$, the lowest was found on anoman 1 dan magnesium. The best combination on stomata was found on gumarang and formula $\mathrm{AB}$, dan the lowest was found on sukmaraja dan magnesium.

\section{References}

Ahmad, Z F. A. waraich, R. Ahmad, M. A. Ikbal dan M. I. Awan. 2015. Studies Screening of Maize (Zea mays L.) Hybrids under Drought Condition. Journal of Advanced Btany and Zoology. Departemen of Agronomy, University of Agriculture Fasisalabad, Pakistan : 2 (4): $1-5$.

Aminian, R., Mohammadi, S. and Hoshmand, S. 2011. Chromosomal Analysis of Photosynthesis Rate and Stomatal Conductance and Their Ralationships with Grain Yeild in Wheat (triticum aestivum L.) under Water-cekaman and Well-watered Condition. Acta Physiol Plant. 33: 755-764.

BPS (Badan Pusat Statistik). 2015. www.bpsaceh.go.id

Bukvice, G., M. Antunovic, S. Poovic, M. Rastiya, 2003. Effect of P and Zn fertilization on biomass, yield and its uptake by maize lines (Zea mays L.). Plant Soil Environ., 49: 505510.

Cakir, R., 2004. Effect of Water at Different Development Stages on Vegetative and Reproductive Growth of Corn. Field Crop Research, 89 (1): 1-16.

Cakmak I, Kirkby EA. 2008. Role of Magnesium in Carbonpartitioning and Alleviating Photooxidative Damage. Physiol Plant 133:692-704.

Cakmak and Yazici, A.M. 2010. Magnesiunm: a forgotten element in crop production. Better crops 94;23-25.s

Devid, CN , A D. Halvarson dan M. F. Vigil. 2010. Critical Presivitation Period for Dryland Maize Production. Field Crops Research: 118: 259 - 253.

Feng, R., Y. Zhang, W. Yu, W. Hu, J. Wu, R. Ji. H. Wang and X. Zhao. 2013. Analysis of Relationship Between The Spectral Characteristics of Maize and Leaf Area Index Drought Cekaman . Acta Ecologica Sinica. 33: 301 - 307.

Gransee A, Fu"hrs H. 2013. Magnesium Obility in Soils as a Challenge for Soil and Plant Analysis, Magnesium Fertilization and Root Uptake under Adverse Growth Gonditions. Plant Soil 368:5-21.

Hardter R, M. Rex and K. Orlovius. 2004. Effect of different Mg fertilizer sources on magnesium availability in soils. Nutr Cycl Agroecosyst 70;249-259.

Jaleel, C. A.,Manivannan, P., Wahid, A., Farooq, M., Somasundaram, R and Paneerselvam, R. 2009. Drought Cekaman in Plant: a Review on Morphological Characteristics and 
Pigments Composition, International Journal Agriculture and Biology, $11: 100-105$.

Janmohammadi, M., P. M. Dezfuli dan F. Shariefzadeh. 2008. Seed Invigoration Techniques to Improve Generation and Growth of Inbred Line of Maize Under Salinity and Drought. Departemen of Crop Physiology University of Tehran, Karaj. 34 (3-4 ): 215-226.

Jezek M, Geilfus CM, Bayer A, Muehling KH. 2015. Photosynthetic Capacity, Nutrient Status, and Growth of Maize (Zea mays L.) upon MgSO4 Leaf-application. Front Plant Sci 5:Art 781.

Katerji, N., J.W. Van Hoorn, A. Hamdy and M. Mastrorilli, 2004. Comparison of corn yield response to plant water cekaman caused by salinity and by drought. Agr. Water Manage., 65: 95-101.

Khavari Khorasani, S., 2008. Applied Science Guide to The Planting and Harvesting of Maize. Serva Press, 119.

Naghavp, M. R., A. Poura bougha daareh ang Khalilp. 2013. Evaluation Drought Tolerance Indeces for Screening Some of Corn (Zea mays L.) Cultivar Under Environmental onditions. Payame Noor University, Departement of Agriculture Ilam, Iran. Not Sci Biol . 5 (12) : $388-393$.

Rabbani, J., Y. Emam, 2011. Response of Seed Yield to Water Cekaman at Different Growth Stages of Maize Hybrids. Production and Processing of Agricultural and Horticultural Products, 1(2): 65-78.

Sajedi, N., M. Ardekani, A. Naderi, H. Madani, M. Mashhadi Akbar Bojar, 2009. Effect of water deficit and application of nutrient elements on yield, yield components and water use efficiency of corn. Iranian Journal of Agricultural Research, 7(2): 493-503.

Tida Ge, Fanggong Sui, Liping Bai, Chengli Tong and Ningho Sun, 2012. Effects of water Cekaman on Growth, Biomasasa Partitioning, and Water-use Efficiency in Summer Maize (Zea mays L ) Throughout The Growth Cycle. Original Paper. Institute of Plant Physiology Polish Academy of Science, Kracow : (34) : 1043-1053.

Wang, K and Shangguan, Z. 2010. Photosynthetic Rharacteristin and Resource Ultilization Efficiency of Maize (Zea mays L.) and Millet (Setaria italica L.) in a Semi-arid Hilly Loess Egion in China-New Zeal. J. Crop Hort. Sci. 38: 247-254.

Zhang, S-Q., Outlaw, W-H., Aghoram, K., 2001. Relationship Between Changes in The Guard Cell Abscisic Acid Content and Others related Physiological Parameters in Intact Plants, Journal of Experimental Botany, 52: 301-308.

Zhang LiXin, Sheng Xiu L and Zong Suo. 2010. Differential Plant Growth and Osmotic of Two Maize (Zea maysL.) Cultivars to Exogenous Glycine betaine Aplication Under Drought. Plant Growth Regul 58 : 297 - 305. 